\title{
Response of Soybean [Glycine $\max$ (L.) Merrill] to Sources and Levels of Phosphorus
}

\author{
K. Nandini Devi (Corresponding author) \\ Department of Agronomy, Central Agricultural University, Imphal, Manipur 795001, India \\ E-mail: nandini_devi2000@yahoo.com \\ L. Nongdren Khomba Singh \\ Department of Plant Protection, Central Agricultural University, Imphal, Manipur 795001, India \\ E-mail: nongdren1966@gmail.com
}

\section{T. Sunanda Devi}

Directorate of Research, Central Agricultural University, Imphal, Manipur 795001, India

E-mail: sunandabckv@gmail.com

H. Nanita Devi

Directorate of Research, Central Agricultural University, Imphal, Manipur 795001, India

E-mail: nita_hei@yahoo.com

T. Basanta Singh

Department of Agricultural Chemistry and Soil Science

Bidhan Chandra KrishiViswavidyalaya, Mohanpur-741234, West Bengal, India

E-mail: basantasingh.t@gmail.com

K. Khamba Singh

Department of Biochemistry, Manipur College, Imphal, Manipur 795001, India

E-mail:khambadr@rediffmail.com

W. Mohendro Singh

Microbial Resources Division, Institute of Bio-resources and Sustainable Development

Takyelpat, Imphal 795001, India

E-mail: mohend_wakambam@yahoo.co.in

Received: January 9, 2012 Accepted: January 19, 2012 Online Published: April 17, 2012

doi:10.5539/jas.v4n6p44

URL: http://dx.doi.org/10.5539/jas.v4n6p44

\begin{abstract}
A field experiment was conducted during rainy seasons of 2007-2009 in India (Manipur) to study the effect of different sources and levels of phosphorus on productivity of soybean [Glycine max (L.) Merrill]. The treatments consisted of four sources of phosphorus [Single super phosphate (SSP), Di-ammonium phosphate (DAP), Single super phosphate (SSP)+Phosphate solubilizing bacteria (PSB), Di-ammonium phosphate (DAP)+Phosphate solubilizing bacteria (PSB)], four levels of phosphorus (20, 40, 60 and $80 \mathrm{~kg} \mathrm{P}_{2} \mathrm{O}_{5}$ ha $^{-1}$ ) and one absolute control(without any fertilizer and PSB). Application of SSP+PSB produced significantly higher number of nodules per plant, dry weight of nodules per plant, number of pods per plant and 100-seed weight than the other treatments. Maximum grain yield and total phosphorus uptake were also recorded when using SSP+PSB. Yield
\end{abstract}


attributing characters, grain and stover yield were increased with increasing levels of phosphorus. Regarding evaluation of various efficiency fractions of soybean, agronomic efficiency, physiological efficiency and phosphorus use efficiency had more pronounced effects on combined application of SSP+PSB. However, apparent recovery of phosphorus was higher in DAP+PSB due to higher stover yield and higher phosphorus uptake. Among the different levels the efficiency fractions increase up to $60 \mathrm{~kg} \mathrm{P}_{2} \mathrm{O}_{5} \mathrm{ha}^{-1}$ and declined at $80 \mathrm{~kg}$ $\mathrm{P}_{2} \mathrm{O}_{5}$ ha $^{-1}$.

Keywords: Soybean, Phosphorus sources, PSB, Phosphorus levels, Agronomic efficiency, Apparent recovery, Phosphorus use efficiency

\section{Introduction}

Phosphorus is an important plant nutrient involved in several energy transformation and biochemical reactions including biological nitrogen fixation. Phosphatic fertilizers have low efficiency of utilization due to chemical fixation in soil (Gaur, 1983) and poor solubility of native soil phosphorus, sometimes there is a buildup of insoluble phosphorus as a result of chemical phosphorus application (Dubey, 1997). Root development, stalk and stem strength, flower and seed formation, crop maturity and production, crop quality, and resistance to plant diseases are the attributes associated with phosphorus nutrition. Although microbial inoculants are in use for improving soil fertility during the last century, however, a meager work has been reported on P solubilization compared to nitrogen fixation. Soil $\mathrm{P}$ dynamics is characterized by physicochemical (sorption-desorption) and biological (immobilization-mineralization) processes. $\mathrm{P}$ is needed in relatively large amounts by legumes for growth and nitrogen fixation and has been reported to promote leaf area, biomass, yield, nodule number, nodule mass, etc., in a number of legumes (Berg and Lynd, 1985; Pacovsky, et al., 1986; Kasturikrishna and Ahlawat, 1999). Phosphorus deficiency can limit nodulation by legumes and $P$ fertilizer application can overcome the deficiency (Carsky, et al., 2001).

Large amount of $\mathrm{P}$ applied as fertilizer enters into the immobile pools through precipitation reaction with highly reactive aluminium $\left(\mathrm{Al}^{+}\right)$and iron $\left(\mathrm{Fe}^{3+}\right)$ in acidic, and calcium $\left(\mathrm{Ca}^{2+}\right)$ in calcareous or normal soils (Gyaneshwar et al., 2002; Hao, et al., 2002). Efficiency of P fertilizer throughout the world is around 10-25\% (Isherword, 1998), and concentration of bioavailable $\mathrm{P}$ in soil is very low reaching the level of $1.0 \mathrm{mg} \mathrm{kg}^{-}{ }^{1}$ soil (Goldstein, 1994). Soil microorganisms play a key role in soil $\mathrm{P}$ dynamics and subsequent availability of phosphate to plants (Richardson, 2001). Microbial community influences soil fertility through soil processes viz. decomposition, mineralization, and storage/release of nutrients. Microorganisms enhance the $\mathrm{P}$ availability to plants by mineralizing organic $\mathrm{P}$ in soil and by solubilizing precipitated phosphates (Chen, et al., 2006; Kang, et al., 2002; Pradhan and Sukla, 2005). Phosphate solubilizing bacteria (PSB) are being used as biofertilizer since 1950s (Kudashev, 1956; Krasilinikov, 1957). Release of P by PSB from insoluble and fixed/adsorbed forms is an import aspect regarding $P$ availability in soils. There are strong evidences that soil bacteria are capable of transforming soil $\mathrm{P}$ to the forms available to plant. Microbial biomass assimilates soluble P, and prevents it from adsorption or fixation (Khan and Joergesen, 2009). Nutritional capacity of Single Super Phosphate (SSP) was further improved by PSB inoculation due to its ability to convert sparingly soluble inorganic phosphate into soluble forms by secreting organic acids (Arora and Gaur, 1979). Microorganisms through secretion of different types of organic acids like carboxylic acid (Deubel and Merbach, 2005) and rhizosphere $\mathrm{pH}$ lowering mechanisms (He and Zhu, 1988) dissociate the bound forms of phosphate like $\mathrm{Ca}_{3}\left(\mathrm{PO}_{4}\right)_{2}$. Among various factors that can contribute to soybean success, phosphorus and inoculation had quite prominent effects on nodulation, growth and yield parameters (Kumaga and Ofori, 2004). It is well known that more than two-third of phosphatic fertilizers are render unavailable within a very short period of time after its application due to fixation in soil complex as di and tri-calcium phosphate (Mandal and Khan, 1972). Application of phosphorus along with phosphate solubilizing bacteria (PSB) improved phosphorus uptake by plants and yields indicating that the PSB are able to solubilize phosphates and to mobilize phosphorus in crop plants (Rogers and Wolfram, 1993). In this respect, biofertilization technology has taken a part to minimize production costs and at the same time avoid the environmental hazards (Galal, et al., 2001). With the above-mentioned facts the study was undertaken to investigate the best source and level of phosphorus on yield attributes, yield and quality of seed and efficiency of phosphorus in soybean.

\section{Materials and Methods}

Field experiments were conducted for three consecutive years at the Agricultural Research Station of Central Agricultural University, Imphal, India during 2007-2009 under All India Coordinated Research Project on Soybean. The soil was clay loamy in texture with $\mathrm{pH}$ of 5.5, low in organic carbon $(0.50 \%)$, available nitrogen $\left(218 \mathrm{~kg} \mathrm{ha}^{-1}\right)$, available $\mathrm{P}_{2} \mathrm{O}_{5}\left(16.5 \mathrm{~kg} \mathrm{ha}^{-1}\right)$ and available $\mathrm{K}_{2} \mathrm{O}\left(186 \mathrm{~kg} \mathrm{ha}^{-1}\right)$. The treatments consisted of four sources of phosphorus [Single super phosphate (SSP), Di-ammonium phosphate (DAP), Single super phosphate 
(SSP) + Phosphate solubilizing bacteria (PSB), and Di-ammonium phosphate (DAP) + Phosphate solubilizing bacteria (PSB)], four levels of phosphorus (20, 40, 60 and $80 \mathrm{~kg} \mathrm{P}_{2} \mathrm{O}_{5} \mathrm{ha}^{-1}$ ) and one absolute control (without any fertilizer and PSB). All the doses of phosphorus treatments and recommended doses of nitrogen $\left(20 \mathrm{~kg}^{-1}\right)$ and potassium $\left(40 \mathrm{~kg}^{1}{ }^{1}\right)$ were applied as basal before sowing. Nitrogen supplied from DAP treatment was calculated and adjusted with the recommended dose to be applied without considering the available nitrogen in soil. Soybean seeds were inoculated with the Phosphate solubilizing bacterial (stain Pseudomonas striataculture) at $5 \mathrm{~g} \mathrm{~kg}^{-1}$ seed before sowing as per treatment. Soybean was sown at a spacing of $45 \mathrm{~cm} \mathrm{x} 10 \mathrm{cmwith}$ a rate of $60 \mathrm{~kg}$ seeds ha ${ }^{-1}$. One hand weeding was done at 30 days after sowing. The crop was sown in the first week of June and harvested in the second week of October in all the experimental years.

\subsection{Growth Characteristics and Nodulation}

Plant height was recorded at the time of maturity. Data on nodulation were recorded from five randomly selected plants at 60 days after sowing. Plants were carefully uprooted from each plot so that no nodules were left in the soil. The roots were thoroughly washed in water and the nodules from the roots of each plant were separately collected and counted. The nodules were air-dried in the oven at $65^{\circ} \mathrm{C}$ for $72 \mathrm{hr}$. Then the dry weights of the nodules were recorded.

\subsection{Yield and Its Component Characteristics}

Yield and its components such as number of pods plant ${ }^{-1}$, number of seed pod $^{-1}$, hundred seed weight, grain yield and stover yield were determined at maturity stage.

\subsection{Chemical Analysis}

Foliar diagnosis was done in the fully youngest expanded leaf, picked at the crop flowering stage. Leaves and grain samples from each plot were oven dried at $70^{\circ} \mathrm{C}$ for constant weight and ground for determination of total nitrogen, phosphorus and oil contents.

\subsubsection{Determination of Available Phosphorous}

Available phosphorus was estimated by Bray's and Kurtz No.1 method (Jackson, 1973).

\subsubsection{Estimation of Oil Content}

The oil content of soybean seeds was estimated by adopting Soxhlet Ether Extraction method (Sadasivam and Manickam, 1996).

\subsubsection{Estimation of Protein}

Total nitrogen content of soybean grain was determined by Micro-Kjeldahl method as recommended by the Association of Official Analytical Chemists (AOAC, 1975), with modifications. Nitrogen contents were multiplied by dry matter-based factor 5.71 to determined total protein content (Sadasivam and Manickam, 1996).

\subsection{Nutrient Uptake}

Nutrient uptake was calculated by multiplying the phosphorus content of soybean grain and stover with their respective yield.

\subsection{Phosphorus Efficiency}

Beneficial effects of the different sources and levels of phosphorus were assessed by calculating the following parameters according to Mengel and Kirkby (2001).

Agronomic Efficiency of $\mathrm{P}\left(\mathrm{kg} \mathrm{kg}^{-1}\right)=($ yield $\mathrm{F}-$ yield C)/ Fertilizer $\mathrm{P}$ applied.

Physiological Efficiency of $\mathrm{P}\left(\mathrm{kg} \mathrm{kg}^{-1}\right)=($ yield $\mathrm{F}-$ yield $\mathrm{C}) /(\mathrm{P}$ uptake $\mathrm{F}-\mathrm{P}$ uptake $\mathrm{C})$

Apparent P Recovery (\%) = (P uptake F $-\mathrm{P}$ uptake C $) /($ Fertilizer P applied $)$ x 100.

Where, $\quad \mathrm{F}=$ Fertilizer applied

$\mathrm{C}=$ Control (without fertilizer).

Phosphorus use efficiency (PUE) was calculated as per Goodroad and Jellum (1998).

PUE (\%) = Physiological efficiency of $\mathrm{P} x$ Apparent P recovery.

\subsection{Experimental Design and Statistical Analysis}

In all, 17 treatments were tested in two-factor randomized block design with three replications. All the data pertaining to the present investigation were statistically analyzed as per the method described by Gomez and Gomez (1984). The statistically significance of various effects was tested at 5 per cent level of probability. 


\section{Results and Discussion}

\subsection{Sources of Phosphorus}

\subsubsection{Effect of Sources of Phosphorus on Growth and Nodulation}

The data in Table 1 revealed that the different sources of phosphorus influenced significantly plant height. Maximum plant height $(52.75 \mathrm{~cm})$ was recorded from the treatment DAP+PSB followed by SSP+PSB $(49.75 \mathrm{~cm})$ and the lowest $(25.33 \mathrm{~cm})$ from control. Microorganisms with phosphate solubilizing potential increase the availability of soluble phosphate and enhance the plant growth by improving biological nitrogen fixation (Kucey, et al., 1989; Ponmurugan and Gopi, 2006). Different sources of phosphorus also influenced significantly the number of nodules plant ${ }^{-1}$ at 60 days after sowing. Combine application of SSP and PSB produced significantly higher number of nodules plant ${ }^{-1}$ (32.23) and the lowest from control (21.00). The increase in nodule number with P may have a diluting effect, as P is known to stimulate nodulation (Sarkar and Mukherjee, 1991; Ankomah, et al., 1996). Legumes require phosphorus for adequate growth and nitrogen fixation (Griller and Cadisch, 1995). Phosphorus deficiency can limit nodulation by legumes and phosphorus fertilizer application can overcome the deficiency (Carsky, et al., 2001). The treatment SSP+PSB produced maximum dry weight of nodules plant ${ }^{-1}$ $(143 \mathrm{mg})$ and the lowest $(113 \mathrm{mg})$ was obtained from the control. It might be due to more number of nodules plant $^{-1}$. Phosphorus deficiency has been shown to restrict severely the nodulation process in soybean. Phosphorus has specific role in nodule initiation, growth and function in addition to its role in host plant growth.

\subsubsection{Effect of Sources of Phosphorus on Yield and Its Attributes}

The data in Table 1 revealed that different yield attributing characteristics of soybean like number of pods plant ${ }^{-1}$, number of seeds pod $^{-1}$ and hundred seed weight were significantly influenced by different sources of phosphorus. Maximum number of pods plant ${ }^{-1}$ (72.92) was recorded from the treatment SSP+PSB and the lowest (29.67) was obtained from the control. The number of seeds $\operatorname{pod}^{-1}$ is perceived a significant constituent that directly imparts in exploiting potential yield recovery in leguminous crops. The number of seeds pod ${ }^{-1}$ obtained from SSP+PSB was found to be at par with that of DAP+PSP but it was significantly higher than SSP and DAP alone. It shows that when SSP or DAP was applied alone without PSP the phosphorus become unavailable to plant at later growth stages. Similarly, hundred seed weight was also maximum treated with SSP + PSB (13.27g) followed by DAP + PSB (13.23g) and the lowest (10.73g) was obtained from the control. Better growth and development of crop plants due to phosphorus supply and nitrogen uptake might have increased the supply of assimilates to seed, which ultimately gained more weight. Similar achievements on hundred seed weight with phosphorus are reported by Kar, et al. (1989), Singh and Hiremath (1990), Chauhan, et al. (1992) and Anchal, et al. (1997).

The effect of different sources of phosphorus on soybean grain and stover yield was found to be significant. Maximum grain yield (1529 kg ha-1) was obtained from SSP+PSB followed by DAP+PSB (1447 kg ha $\left.{ }^{-1}\right)$. This might be due to the cumulative favorable effect of higher number of pods plant ${ }^{-1}$ and higher hundred seed weight (Table 1). The better performance of SSP+PSP compared to other sources might be attributed to readily available phosphorus resulting in better absorption and utilization of phosphorus by plant and presence of other important plant nutrients i.e. sulphur. Sulphur, besides increasing phosphorus availability (Sacchidanand, et al., 1980) also increases its assimilation rate. Phosphate solubilizing bacteria enhance the phosphorus availability to plants by mineralizing organic $\mathrm{P}$ in soil and by solubilizing precipitated phosphate (Chen, et al., 2006; Kang, et al., 2002; Pradhan and Sukla, 2005). Badret (1986), Dubey, et al. (1997) have also reported significant increases in grain yield of soybean due to co-inoculation of phosphorus solubilizers. Higher crop yields resulted from solubilization of fixed soil P and applied phosphates by PSB (Zaidi, 1999). Phosphorus has important effects on photosynthesis, nitrogen fixation, root development, flowering, seed formation, fruiting and improvement of crop quality (Brady, 2002). The maximum stover yield $\left(2394 \mathrm{~kg} \mathrm{ha}^{-1}\right)$ was obtained from the treatment DAP+PSB and the lowest $\left(1073 \mathrm{~kg} \mathrm{ha}^{-1}\right)$ was obtained from the control. This might be due to the combine effect of DAP, which contains both phosphorus and nitrogen as well as enhancement of phosphorus availability to plants by mineralizing organic phosphorus in soil and by solubilizing precipitated phosphates.

\subsubsection{Effect of Sources of Phosphorus on Oil and Protein Content of Soybean Seed and Their Yield}

Oil and protein content of soybean seed was significantly influenced by different sources of phosphorus (Table 2). Application of SSP+PSP significantly produced higher oil content $(18.53 \%)$ ), and protein content (35.35\%) and the lowest were in the control. This might be due to the presence of sulphur in SSP, which is involved in the synthesis of fatty acids and also increase protein quality through the synthesis of certain amino acids such as cysteine and methionine. It is evident from the results that sulphur had remarkable influence on oil and protein content. Similar findings were also reported by Havlin, et al. (1999) and Kandpal and Chandel (1993). Phosphate solubilizing bacteria also are capable of transforming soil phosphorus to the forms available to plant. Similarly, 
oil and protein yield were also maximum with the treatment SSP+PSB. This was due to higher oil and protein content of seed as well as higher grain yield per unit area.

\subsubsection{Effect of Sources of Phosphorus on Phosphorus Uptake and Efficiency}

Phosphorus uptake by seed was maximum $\left(6.28 \mathrm{~kg} \mathrm{ha}^{-1}\right)$ with treatment SSP+PSB and the lowest from control $\left(2.8 \mathrm{~kg} \mathrm{ha}^{-1}\right)$. This might be due to higher phosphorus content in seed and higher seed yield. In contrast, phosphorus uptake by stover was maximum $\left(7.52 \mathrm{~kg} \mathrm{ha}^{-1}\right)$ with DAP+PSB. This might be due to higher yield of stover as well as phosphorus content in stover. But the total uptake of phosphorus was found to be at par with the treatments SSP+PSB and DAP+PSP.

Agronomic efficiency of phosphorus was significantly influenced by different sources of phosphorus. Combined application of SSP and PSB significantly produced higher agronomic efficiency of phosphorus than the other sources of phosphorus. It was 47, 28.23 and 15.49 percent higher than SSP, DAP and DAP+PSP, respectively. Whalen and Chang (2001) also reported that effectiveness of inorganic phosphorus fertilizers was increased by the addition of organic manure. Phosphorus recovery was found to be at par with SSP+PSB and DAP+PSB. It was significantly higher than that when applied SSP or DAP alone. This might be due to higher grain and stover yield as well as more phosphorus uptake. Physiological efficiency of phosphorus (PEP) and phosphorus use efficiency (PUE) was also influenced by different sources of phosphorus. Application of SSP+PSB and $\mathrm{DAP}+\mathrm{PSB}$ produced maximum physiological efficiency of phosphorus (PEP) and phosphorus use efficiency (PUE) than using SSP or DAP alone (Table 3). This might be due to improved efficiency of the phosphorus fertilizers by the activity of phosphate solubilizing bacteria. Effectiveness of inorganic phosphorus was increased and phosphorus recovery was improved with the addition of organic manure (Whalen and Chang, 2001). Cassman, et al. (2002) also reported that nutrient efficiency was greatly affected by the amount of nutrient used and by the synchronization between demand and supply of the nutrients. Shah, et al. (2001) also reported phosphorus uptake efficiency and yield increased with phosphorus application and with inoculation.

\subsection{Levels of Phosphorus}

\subsubsection{Effect of Level of Phosphorus on Growth and Nodulation}

The data in Table 1 revealed that plant height, number of nodules plant ${ }^{-1}$ and nodule dry weight plant ${ }^{-1}$ significantly increased by increasing levels of phosphorus. Application of $80 \mathrm{~kg} \mathrm{P}_{2} \mathrm{O}_{5} \mathrm{ha}^{-1}$ produced maximum plant height $(47.75 \mathrm{~cm})$, number of nodules plant ${ }^{-1}(35.67)$ and nodule dry weight $\left(152 \mathrm{mg} \mathrm{plant}^{-1}\right)$. The lowest was recorded from control. As it is known, phosphorus is involved in several energy transformation processes and biochemical reactions including nitrogen fixation. Root development, stalk and stem strength, and nitrogen fixation in legumes are attributes associated with phosphorus nutrition. It shows that phosphorus is needed in relatively large amounts by legumes for growth and nitrogen fixation and has been reported to promote biomass yield, nodule number, nodule mass etc., in a number of leguminous crops (Berg and Lynd, 1985; Pacovsky, et al., 1986; Kashurikrishna and Aulawat, 1999).

\subsubsection{Effect of Levels of Phosphorus on Yield Attributes and Yield}

Application of different levels of phosphorus significantly influenced yield attributing characteristics of soybean like number of pods plant ${ }^{-1}$, number of seeds $\operatorname{pod}^{-1}$ and hundred seed weight. Application of phosphorus at $80 \mathrm{~kg}$ $\mathrm{ha}^{-1}$ produced maximum number of pods plant ${ }^{-1}(76.25)$, seeds pod $^{-1}(2.84)$ and hundred seed weight $(13.43 \mathrm{~g})$ and the lowest was obtained from the control. Hernandez and Cuevas (2003) also reported significant high number of seeds pod ${ }^{-1}$ was recorded when $100 \mathrm{~kg} \mathrm{P}_{2} \mathrm{O}_{5}$ ha $^{-1}$ was applied and minimum number of seeds pod $^{-1}$ when no phosphorus was applied. These results confirm the findings of Tomar, et al. (2004) who also observed significant differences in number of seeds pod $^{-1}$ when inoculation and different levels of phosphorus were applied.

Grain and stover yield of soybean was also increased with increasing level of phosphorus fertilizer. The maximum grain yield $\left(1656 \mathrm{~kg} \mathrm{ha}^{-1}\right)$ produced by the application of $80 \mathrm{~kg} \mathrm{P}_{2} \mathrm{O}_{5} \mathrm{ha}^{-1}$ was found to be at par with that of $60 \mathrm{~kg} \mathrm{P}_{2} \mathrm{O}_{5}$ ha $^{-1}$. The increase in seed yield might be due to more number of pods plant ${ }^{-1}$, seeds pod ${ }^{-1}$ and/or hundred seed weight. The low yield of soybean grain at lower levels of phosphorus was probably due to lesser magnitude of phosphorus response. Stefanescu and Palanciuc (2000); Landge, et al. (2002); Umale, et al. (2002); Ilbas and Sahn (2005); Tapas and Gupta (2005) and Jain and Trivedi (2005) also reported that seed yield of soybean increase with inoculation and applying higher levels of phosphorus. Maximum stover yield $(2735 \mathrm{~kg}$ $\mathrm{ha}^{-1}$ ) was obtained from the application of $80 \mathrm{~kg} \mathrm{P}_{2} \mathrm{O}_{5} \mathrm{ha}^{-1}$ followed by $60 \mathrm{~kg} \mathrm{P}_{2} \mathrm{O}_{5} \mathrm{ha}^{-1}\left(2363 \mathrm{~kg} \mathrm{ha}^{-1}\right)$. The higher value of stover yield at higher level of phosphorus is owing to significantly higher value of dry matter per 
plant besides the other growth and yield parameters. These findings are in conformity with the results of Sarkar, et al. (1997).

\subsubsection{Effect of Levels of Phosphorus on Oil, Protein Content and Its Yield}

Oil content of soybean seed increases with increasing levels of phosphorus fertilizer (Prasad, et al., 1991). Similarly oil yield was also increased in the same trend. This might be due to higher oil content as well as higher grain yield. Similar finding was also reported by Tomar, et al. (2004) who observed that inoculation and phosphorus application increased oil contents of soybean. Mehasen, et al. (2002) and Bardan (2003) also reported that more oil yield was produced when inoculation and higher doses of phosphorus were applied. Apart from other factors, quality of crop depends upon the protein content of seed, which is the major constituent of seed in legumes. The maximum seed protein content (35.2 percent) was achieved by using $80 \mathrm{~kg} \mathrm{P}_{2} \mathrm{O}_{5} \mathrm{ha}^{-1}$. In our study significantly lowest protein content (32.40 percent) was observed from control. In the same trend protein yield was also higher $\left(511 \mathrm{~kg} \mathrm{ha}^{-1}\right)$ when using $80 \mathrm{~kg} \mathrm{P}_{2} \mathrm{O}_{5} \mathrm{ha}^{-1}$ and the lowest $\left(287 \mathrm{~kg} \mathrm{ha}^{-1}\right)$ was obtained from the control (Table 2.).

\subsubsection{Effect of Levels of Phosphorus on Phosphorus Uptake and Efficiency}

Total uptake phosphorus by soybean increases with increasing levels of phosphorus. The increased uptake of phosphorus was due to added supply of nutrients and well developed root system resulting in better absorption of water and nutrient. Maximum phosphorus uptake was obtained from $80 \mathrm{~kg} \mathrm{P}_{2} \mathrm{O}_{5} \mathrm{ha}^{-1}$ and the lowest was obtained from the control (Table 3). Kumar and Kushwaha (2006) also reported that total phosphorus uptake by pigeon pea significantly increased with increasing phosphorus level due to higher amount of biomass production and subsequently greater phosphorus accumulation by the plant. Shankaralingappa, et al. (2000) also made similar observations.

Maximum agronomic efficiency of phosphorus (APUE) was observed from $60 \mathrm{~kg}_{2} \mathrm{O}_{5} \mathrm{ha}^{-1}$ owing to greater grain production per unit of phosphorus applied. Apparent phosphorus recovery was highest when using $40 \mathrm{~kg}$ $\mathrm{P}_{2} \mathrm{O}_{5}$ ha $^{-1}$ (Table 3). The declined in APUE and apparent phosphorus recovery with higher level of phosphorus might be due to fixation of phosphorus in the soil. In the same trend phosphorus use efficiency was also increased up to $60 \mathrm{~kg} \mathrm{P}_{2} \mathrm{O}_{5} \mathrm{ha}^{-1}$ and declined at higher level. Similar result was also reported by Kumar and Kushwaha (2006).

\section{Conclusion}

From the above-mentioned results, it can be inferred that application of SSP+PSB significantly proved effective in enhancing the nodulation, yield attributes and yield of soybean. Similarly, agronomic efficiency of phosphorus, physiological efficiency and phosphorus use efficiency were also higher with applying SSP+PSB. The growth, yield attributes and yield were increased with increasing phosphorus levels. The efficiency fractions were increased up to $60 \mathrm{~kg} \mathrm{P}_{2} \mathrm{O}_{5} \mathrm{ha}^{-1}$ and declined at $80 \mathrm{~kg} \mathrm{P}_{2} \mathrm{O}_{5} \mathrm{ha}^{-1}$.

\section{Acknowledgement}

The authors are thankful to Indian Council of Agricultural Research (ICAR) for funding the All India Coordinated Research Project on Soybean, Dr. S. N. Puri, hon'ble Vice-chancellor and Incharge Director of Research for technical support to carry out this field experiment.

\section{References}

Anchal, D., Kharwara, P. C., Rana, S. S., \& Dass, A. (1997). Response of gram varieties to sowing dates and phosphorus levels under on farm condition. Himachal J. Agric. Res., 23, 112-5.

A. O. A. C. (1975). Association of Official Agriculture Chemists. Official Methods of analysis $12^{\text {th }}$ Ed. Washington, D.C. USA.

Ankomah, A. B., Zapata, F., \& Hardarson, G. (1996). Yield, nodulation and $\mathrm{N}_{2}$ fixation by cowpea cultivars at different phosphorus levels. Biol. Fert. Soils, 22, 10-15. http://dx.doi.org/10.1007/BF00384426

Arora, D., \& Gaur, A. C. (1979). Microbial solubilization of different inorganic phosphates. Indian J. Exptl. Biol., 17, 1258-1261.

Badret, Din, S. M. S., Khala Fallah, M. A., \& Moawad, H. (1986). Z. PfanzeBodenkonde, 149, 130.

Bardan, M. M. (2003). Effect of nitrogenous and phosphetic fertilization on some economical characters of soybean Crawford cultivar under calcareous soil conditions. Egyptian J. Agric. Res., 81(2), 433-440.

Berg, R. K., \& Lynd, J. Q. (1985). Soil fertility effects on growth, yield, nodulation and nitrogenase activity of Australian winter pea. J. Plant Nutr., 8, 131-145. http://dx.doi.org/10.1080/01904168509363330 
Brady, N. C. (2002). Phosphorus and potassium. In: The nature and properties of soils. (pp. 352). Prentice - Hall of India, Delhi.

Carsky, R. J., Singh, B. B., \& Oyewole, R. (2001). Contribution of early-season cowpea to late season maize in the savanna zone of West Africa. Biol. Agric. Hort., 18, 303-315.

Cassman, Doberman, K. G. A., \& Walters, D. T. (2002). Agroecosystems, nitrogen use efficiency, and nitrogen management. Ambio, 31, 132-140.

Chauhan, Y. S., Johanson, C., \& Venkataratnam, N. (1992). Effect of phosphorus deficiency on phenology and yield components of short duration pigeonpea. Trop. Agri., 69, 235-8.

Chen, Y. P., Rekha, P. D., Arunshen, A. B., Lai, W. A., \& Young, C. C. (2006). Phosphate solubilizing bacteria from subtropical soil and their tri-calcium phosphate solubilizing abilities. Appl. Soil Ecol., 34, 33-41. http://dx.doi.org/10.1016/j.apsoil.2005.12.002

Deubel, A. G., \& Merbach, W. (2005). Influence of microorganisms on phosphorus bioavailability in soils. In: Buscot, F. and A. Varma (eds.), Micoorganisms in Soils: Roles in Genesis and Functions. (pp. 177-91). Springer -Verlag, Berlin, Heidelberg, Germany. http://dx.doi.org/10.1007/3-540-26609-7_9

Dubey, S. K. (1997). Co-inoculation of phosphorus bacteria with Bradyrhizobiumjaponicum to increase phosphate availability to rainfed soybean in Vertisol. J. Indian Soc. Soil Sci., 45, 506-509.

Dubey, S. K., Balasundaram, V. R., Pant, L. M., Jaysheela, N., Kawale, B. R., \& Mishra, B. (1997). Effect of phosphate dissolving bacteria applied with rock phosphate on nodulation and yield of rainfed soybean under different agroclimatic conditions. J. Indian Soc. Soil Sci., 45, 503-505.

Galal, Y. G., El-Gandaour, J. A., \& El-Akel, F. A. (2001). Stimulation of wheat growth and N-fixation through Azospirillum and Rhizobium inoculation. A field trial with $15 \mathrm{~N}$ techniques, 666-667. In. (W.J. Horst. Eds.). Plant Nutrition- Food Security and Sustainability of Agroecosystems.

Giller, K. E., \& Cadisch, G. (1995). Future benefits from biological nitrogen fixation: an ecological approach to agriculture. Plant Soil, 174, 255-277. http://dx.doi.org/10.1007/BF00032251

Goldstein, A. H. (1994). Involvement of the quinoprotein glucose dehydrogenases in the solubilization of exogenous phosphates by gram-negative bacteria. In: A. TorrianiGorini, E. Yagil and S. Silver (eds.), Phosphate in Microorganisms: Cellular and Molecular Biology. ASM Press, Washington, D.C., pp197-203.

Gomez, A. A., \& Gomez, K. A. (1984). Statistical Procedures for Agricultural Research, John Wiley and Sons, Ink., New York.

Goodroad, L. L., \& Jellum, M. D. (1988). Effect of N fertilizer rate and soil pH on $\mathrm{N}$ efficiency in corn. Plant and Soil, 106, 85-89. http://dx.doi.org/10.1007/BF02371198

Gyaneshwar, P., Kumar, G. N., Parekh, L. J., \& Poole, P. S. (2002). Role of soil microorganisms in improving P nutrition of plants. Plant Soil, 245, 83-93. http://dx.doi.org/10.1023/A:1020663916259

Hao, X., Cho, C. M., Racz, G. J., \& Chang, C. (2002). Chemical retardation of phosphate diffusion in an acid soil as affected by liming. Nutr. Cycl. Agroecosystems, 64, 213-224. http://dx.doi.org/10.1023/A:1021470824083

Havlin, L. J., Beaton, D. J., Tisdale, L. S., \& Nelson, L. W. (1999). Soil fertility and fertilizers. Prentice Hall of Indian. ( $6^{\text {th }}$ ed., pp. 220, 227, 228, 319-346).

He, Z. L., \& Zhu, J. (1988). Microbial utilization and transformation of phosphate adsorbed by variable charged minerals. Soil Biol. Biochem., 30, 917-923. http://dx.doi.org/10.1016/S0038-0717(97)00188-0

Hernandez, M., \& Cuevas, F. (2003). The effect of inoculating with Arbuscularmycorrhiza and Bradyrhizobium strains on soybean (Glycine max (L.) Merrill) crop development. Cultivos - Tropicales, 24(2), 19-21.

Isherword, K. F. (1998). Fertilizer use and environment. In N. Ahmed and A. Hamid (eds.), Proc. Symp. Plant Nutrition Management for Sustainable Agricultural Growth (pp. 57-76.). NFDC, Islamabad.

Ilbas, A. I., \& Sahn, S. (2005). Glomusfasciculatum inoculation improves soybean production. Acta-Agriculture - Scandinavica - section -B, soil and plant sciences. India, 55(4), 287-292.

Jackson, M. L. (1973). Soil chemical analysis. Published by Prentice- Hall of India Pvt. Limited, New Delhi, India, 111-203. 
Jain, P. C., \& Trivedi, S. K. (2005). Response of soybean (Glycine max L.) to phosphorus and biofertilizers. Legume Research, 28(1), 30-33.

Kandpal, B. M., \& Chandel, A. S. (1993). Effect of gypsum and pyrites as sources of sulphur on nitrogen fixation, dry matter yield and quality of soybean (Glycine max). Indian J. of Agron., 38, 137-139.

Kang, S. C., Hat, C. G., Lee, T. G., \& Maheshwari, D. K. (2002). Solubilization of insoluble inorganic phosphates by a soil-inhabiting fungus Fomitopsis sp. PS 102. Curr. Sci., 82, 439-442.

Kar, P.C., Patro, G. K., \& Mohanty, K. (1989). Effect of fertilizer levels on the growth and yield of Bengal gram. Curr. Res. Univ. Agri. Sci., 18, 80-81.

Kashturikrishna, S. \& Ahlawat, P. S. (1999). Growth and yield response of pea (Pisumsativum) to moisture stress, phosphorus, sulphur and zink fertilizers. Indian J. Agron., 44, 588-596.

Khan, K. S., \& Joergensen, R. G. (2009). Changes in microbial biomass and P fractions in biogenic household waste compost amended with inorganic $\mathrm{P}$ fertilizers. Bioresour. Technol., 100, 303-309. http://dx.doi.org/10.1016/j.biortech.2008.06.002

Krasilinikov, N. A. (1957). On the role of soil microorganism in plant nutrition. Microbiologiya, 26, 659-72.

Kucey, R. M. N., Janzen, H. H., \& Legget, M. E. (1989). Microbial mediated increases in plant available phosphorus. Adv. Agron., 42, 199-228. http://dx.doi.org/10.1016/S0065-2113(08)60525-8

Kudashev, I. S. (1956). The effect of phosphobacterin on the yield and protein content in grains of Autumn wheat, maize and soybean. Doki. Akad. Skh. Nauk., 8, 20-23.

Kumaga, F. K., \& Ofori, K. (2004). Response of soybean to Bradyrhizobia inoculation and phosphorus inoculation. Int. J. Agric. and Bio., 6(2), 324-327.

Kumar, Avinash, \& Kushwaha, H. S. (2006). Response of pigeonpea (Cajanuscajan) to sources and levels of phosphorus under rainfed condition. Indian Journal of Agronomy, 51(1), 60-62.

Landge, S. K., Kakade, S. U., Thakare, D. P., Karunkar, P. A., \& Jiotode, J. D. (2002). Response of soybean to nitrogen and phosphorus. Research on Crops, 3(3), 653-655.

Mehasen, S. A. S., Zaghloul, R. A., \& El-Ghozoli, M. A. (2002). Effectiveness of dual inoculation with Bradyrhizobium and Endomycorrhizae in presence of different phosphatic fertilizer sources on growth and yield of soybean. Cairo Annals Agric. Sci., 47(2), 477-500.

Mengel, K., \& Kirkby, E. A. (2001). Principles of Plant Nutrition. $5^{\text {th }}$ Ed., Kluwer Academic Publishers, London. http://dx.doi.org/10.1007/978-94-010-1009-2

Pacovsky, R. S., Bethlenfalvay, G. J., \& Paul, E. A. (1986). Comparisons between P-fertilized and mycorrhizal plants. Crop Sci., 26, 151-156. http://dx.doi.org/10.2135/cropsci1986.0011183X002600010035x

Ponmurugan, P., \& Gopi, C. (2006). Distribution pattern and screening of phosphate solubilizing bacteria isolated from different food and storage crops. J. Agron., 5, 600-604. http://dx.doi.org/10.3923/ja.2006.600.604

Pradhan, N., \& Sukala, L. B. (2005). Solubilization of inorganic phosphate by fungi isolated from agriculture soil. African J. Biotechnol., 5, 850-854.

Prasad, F. M., Sisodla, D. S., Varsheey, M. L., \& Verma, M. M. (1991). Effect of different levels of sulphur and phosphorus on growth, drymatter, oil content and uptake of nutrients by soybean. New Agriculturist, 2(1), 15-18.

Richardson, A. E. (2001). Prospect for using soil microorganisms to improve the acquisition of phosphorus by plants. Aust. J. Plant Physiol., 28, 897-907.

Rogers, R. D., \& Wolfram, J. H. (1993). Phosphorus, Sulphur and Silicon Related Elements, 77(1-4), 137-140. http://dx.doi.org/10.1080/10426509308045638

Sacchidanand, B., Sawarkar, N. J., Ghurayya, R. S., Shinde, D. A., \& Sinha, S. B. (1980). Response of soybean (Glycine max) to sulphur and phosphorus. J. Indian Soc. Soil Sci., 28(2), 189-192.

Sadasivam, S., \& Manickam, A. (1996). Biochemical methods, 22-23. New Age International Pvt. Ltd. Ansari Road, Daryaganj, New Delhi.

Shah, P., Kakar, K. M., \& Zada, K. (2001). Phosphorus use efficiency of soybean as affected by phosphorus application and inoculation. In (W.J. Horst. Eds.). Plant Nutrition-Food Security and Sustainability of Agroecosystems, 670-671. 
Sarkar, A., \& Mukharjee, A. K. (1991). Effects of phosphorus on yield and nodulation of green gram (Phaseolus radiates), black gram (P. mungo) and rice bean (Vigna umbellate). Indian J. Agric. Sci., 61, 328-331.

Sarkar, R. K., Shit, D., \& Chakraborty, A. (1997). Effects of levels and sources of phosphorus with and without farmyard manure on pigeon (Cajanuscajan) under rainfed condition. Indian J. Agro., 42(1), 120-123.

Shankarlingappa, B. C., Shivaraj, B., Sudhir, K., \& Vishwanatha, K. P. (2000). Interaction effect of phosphorus and sulphur on uptake of nitrogen, phosphorus, potassium and by pigeonpea. (Cajanuscajan) Indian Journal of Agronomy, 45(2), 348-352.

Singh, B. G., \& Hiremath, S. M. (1990). Effect of phosphate fertilization on physiological aspects of mungbean. J. Maharashtra Agric. Univ., 15(2), 176-78.

Stefanescu, M., \& Palanciuc, V. (2000). Efficiency of bacterial inoculation and mineral nitrogen and phosphorus fertilization in rainfed soybean. Roma. Agric. Res., 13(14), 75-83.

Tapas, C., \& Gupta, S. B. (2005). Effect of bacterial fertilizers with different phosphorus levels on soybean and soil microflora. Advances in Plant Sciences, Raipur, India, 18(1), 81-86.

Tomar, S. S., Singh, R., \& Singh, P. S. (2004). Response of phosphorus, sulphur and Rhizobium inoculation on growth, yield and quality of soybean. Prog. Agric., 4(1), 72-73.

Umale, S. M., Thosar, V. R., Chorey, A. B., \& Chimote, A. N. (2002). Growth response of soybean to P solubilizing bacteria and phosphorus levels. J. Soils and Crops, 12(2), 258-262.

Whalen, J. K., \& Chang, C. (2001). Phosphorus accumulation in cultivated soils from long-term annual applications of cattle feedlot manure. Journal of Environmental Quality, 30, 229-237. http://dx.doi.org/10.2134/jeq2001.301229x

Zaidi, A. (1999). Synergistic interaction of nitrogen fixing microorganisms with phosphate mobilizing microorganisms. Ph.D. Thesis, Aligarh Muslim University, Aligarh, India.

Table 1. Effect of sources and levels of phosphorus on plant height, nodulation, yield attributes and yield of soybean (average of three years)

\begin{tabular}{|c|c|c|c|c|c|c|c|c|}
\hline Treatment & $\begin{array}{l}\text { Plant } \\
\text { height } \\
(\mathrm{cm})\end{array}$ & $\begin{array}{c}\text { Nodules } \\
\text { plant }^{-1} \text { at } 60 \\
\text { DAS }\end{array}$ & $\begin{array}{c}\text { Nodule dry } \\
\text { weight plant } \\
(\mathrm{mg}) \text { at } 60 \mathrm{DAS}\end{array}$ & $\begin{array}{l}\text { Pods } \\
\text { plant }^{-1}\end{array}$ & $\begin{array}{l}\text { Seed } \\
\text { pod }^{-1}\end{array}$ & $\begin{array}{c}\text { 100-seed } \\
\text { s weight } \\
\text { (g) }\end{array}$ & $\begin{array}{c}\text { Seed } \\
\text { yield } \\
\left(\mathrm{kg} \mathrm{ha}^{-1}\right)\end{array}$ & $\begin{array}{c}\text { Stover } \\
\text { yield } \\
\left(\mathrm{kg} \mathrm{ha}^{-1}\right)\end{array}$ \\
\hline $\begin{array}{l}\text { Absolute control } \\
\text { P sources }\end{array}$ & 25.33 & 21.00 & 113 & 29.67 & 1.90 & 10.73 & 887 & 1073 \\
\hline SSP & 35.00 & 31.08 & 140 & 52.67 & 2.72 & 12.86 & 1334 & 2148 \\
\hline DAP & 36.58 & 30.58 & 136 & 58.92 & 2.73 & 13.12 & 1397 & 2155 \\
\hline $\mathrm{SSP}+\mathrm{PSB}$ & 49.75 & 32.23 & 143 & 72.92 & 2.77 & 13.27 & 1529 & 2256 \\
\hline $\mathrm{DAP}+\mathrm{PSB}$ & 52.75 & 30.75 & 139 & 66.58 & 2.77 & 13.23 & 1447 & 2394 \\
\hline $\mathrm{CD}(\mathrm{P}=0.05)$ & 5.11 & 0.74 & 1.33 & 6.92 & 0.05 & 0.34 & 73.12 & NS \\
\hline \multicolumn{9}{|l|}{$\mathrm{P}$ levels $\left(\mathrm{kg} \mathrm{P}_{2} \mathrm{O}_{5} \mathrm{ha}^{-1}\right)$} \\
\hline 20 & 40.25 & 23.25 & 123 & 45.83 & 2.65 & 12.21 & 1055 & 1616 \\
\hline 40 & 41.50 & 32.42 & 135 & 56.00 & 2.70 & 12.88 & 1342 & 2239 \\
\hline 60 & 44.58 & 33.32 & 149 & 73.00 & 2.80 & 13.25 & 1644 & 2363 \\
\hline 80 & 47.75 & 35.67 & 152 & 76.25 & 2.84 & 13.43 & 1656 & 2735 \\
\hline $\mathrm{CD}(\mathrm{P}=0.05)$ & 5.11 & 0.74 & 1.33 & 6.92 & 0.05 & 0.34 & 73.12 & 312 \\
\hline Interaction $(\mathrm{P}=0.05)$ & 10.21 & 1.48 & 2.66 & 13.92 & 0.11 & NS & NS & NS \\
\hline
\end{tabular}


Table 2. Effect of sources and levels of phosphorus on oil content and protein content of soybean (average of three years)

\begin{tabular}{|c|c|c|c|c|}
\hline Treatment & $\begin{array}{c}\text { Oil content } \\
(\%)\end{array}$ & $\begin{array}{l}\text { Oil yield } \\
\left(\mathrm{kg} \mathrm{ha}^{-1}\right)\end{array}$ & $\begin{array}{c}\text { Protein content } \\
(\%)\end{array}$ & $\begin{array}{c}\text { Protein yield } \\
\left(\mathrm{kg} \mathrm{ha}^{-1}\right)\end{array}$ \\
\hline Absolute control & 13.67 & 121 & 32.40 & 287 \\
\hline \multicolumn{5}{|l|}{ P sources } \\
\hline $\mathrm{SSP}$ & 16.25 & 217 & 34.91 & 469 \\
\hline DAP & 16.58 & 232 & 34.88 & 489 \\
\hline SSP + PSB & 18.53 & 285 & 35.35 & 545 \\
\hline $\mathrm{DAP}+\mathrm{PSB}$ & 17.71 & 256 & 35.20 & 511 \\
\hline $\mathrm{CD}(\mathrm{P}=0.05)$ & 0.42 & 13.87 & 0.14 & 25.22 \\
\hline \multicolumn{5}{|l|}{$\mathrm{P}$ levels $\left(\mathrm{kg} \mathrm{P}_{2} \mathrm{O}_{5} \mathrm{ha}^{-1}\right)$} \\
\hline 20 & 17.08 & 180 & 33.72 & 356 \\
\hline 40 & 17.08 & 230 & 34.25 & 460 \\
\hline 60 & 17.28 & 285 & 35.95 & 591 \\
\hline 80 & 17.63 & 294 & 36.42 & 607 \\
\hline $\mathrm{CD}(\mathrm{P}=0.05)$ & 0.42 & 13.87 & 0.14 & 25.22 \\
\hline Interaction $(\mathrm{P}=0.05)$ & NS & NS & 0.29 & NS \\
\hline
\end{tabular}

Table 3. Effect of sources and levels of phosphorus on P uptake, P efficiencies and economics of soybean (average of three years)

\begin{tabular}{|c|c|c|c|c|c|c|c|}
\hline \multirow[t]{2}{*}{ Treatment } & \multicolumn{3}{|c|}{$\mathrm{P}$ uptake $\left(\mathrm{kg} \mathrm{P}_{2} \mathrm{O}_{5} \mathrm{ha}^{-1}\right)$} & \multirow{2}{*}{$\begin{array}{c}\text { APUE } \\
\left({\mathrm{kg} \text { grain } \mathrm{kg}^{-1}}^{\left.\mathrm{P}_{2} \mathrm{O}_{5}\right)}\right.\end{array}$} & \multirow{2}{*}{$\begin{array}{c}\text { Apparent } \\
\text { P recovery } \\
(\%)\end{array}$} & \multirow{2}{*}{$\begin{array}{c}\text { PEP } \\
\left(\mathrm{kg} \mathrm{kg}^{-1} \mathrm{P}_{2} \mathrm{O}_{5}\right)\end{array}$} & \multirow{2}{*}{$\begin{array}{l}\text { PUE } \\
(\%)\end{array}$} \\
\hline & Grain & Stover & Total & & & & \\
\hline $\begin{array}{l}\text { Absolute control } \\
\text { P sources }\end{array}$ & 2.8 & 2.8 & 5.6 & 0.00 & 0.00 & 0.00 & 0.00 \\
\hline SSP & 5.41 & 6.76 & 12.17 & 8.62 & 12.98 & 67.98 & 8.62 \\
\hline DAP & 5.67 & 6.75 & 12.42 & 9.88 & 13.48 & 73.13 & 9.88 \\
\hline $\mathrm{SSP}+\mathrm{PSB}$ & 6.28 & 7.15 & 13.43 & 12.67 & 15.95 & 79.32 & 12.67 \\
\hline $\mathrm{DAP}+\mathrm{PSB}$ & 5.92 & 7.52 & 13.44 & 10.97 & 16.04 & 69.63 & 10.97 \\
\hline $\mathrm{CD}(\mathrm{P}=0.05)$ & 0.31 & NS & 1.06 & 1.48 & 2.20 & NS & 1.48 \\
\hline \multicolumn{8}{|l|}{$\mathrm{P}$ levels $\left(\mathrm{kg} \mathrm{P}_{2} \mathrm{O}_{5} \mathrm{ha}^{-1}\right)$} \\
\hline 20 & 3.728 & 4.56 & 8.29 & 8.41 & 13.42 & 63.66 & 8.41 \\
\hline 40 & 5.426 & 6.83 & 12.26 & 11.38 & 16.62 & 68.10 & 11.38 \\
\hline 60 & 6.969 & 7.70 & 14.67 & 12.62 & 15.10 & 84.09 & 12.62 \\
\hline 80 & 7.163 & 9.08 & 16.25 & 9.73 & 13.30 & 74.21 & 9.73 \\
\hline $\mathrm{CD}(\mathrm{P}=0.05)$ & 0.31 & 1.00 & 1.06 & 1.48 & 2.20 & 9.77 & 1.48 \\
\hline Interaction $(\mathrm{P}=0.05)$ & NS & NS & NS & NS & NS & NS & NS \\
\hline
\end{tabular}

APUE = Agronomic phosphorus-use efficiency; $\mathrm{PEP}=$ Physiological efficiency of phosphorus; $\mathrm{PUE}=$ Phosphorus-use efficiency 